\title{
EFFICIENCY OF GROWING WINTER WHEAT DEPENDING ON THE SOIL TILLAGE AND SOWING SYSTEMS
}

\author{
A. D. Gyrka', O. O. Viniukov ${ }^{2}$, T. V. Gyrka ${ }^{1}$, O. I. Bokun ${ }^{1}$, A. O. Кулик ${ }^{1}$ \\ ${ }^{1}$ SE Institute of Grain Crops of National Academy of Agrarian Sciences, 14 Volodymyr Vernadskyi Str., \\ Dnipro, 49027, Ukraine \\ ${ }^{2}$ Donetsk State Agricultural Experimental Station of NAAS Ukraine, 1, Gagarin Str, Grishina, Pokrovsky \\ district, Donetsk region, 85330, Ukraine
}

The results of the analysis of the efficiency of winter wheat growing depending on the soil tillage and sowing systems in changing hydrothermal conditions of Steppe zone are presented.

Weather conditions during the investigations were different, but in general favorable, which made it possible to fully assess its influence of soil tillage and sowing systems on growth, development, grain productivity and economic and bioenergy efficiency of winter wheat growing. It is established, that the highest grain yield of winter wheat was formed in the variant of surface soil tillage and seeding with ATD6.35 and was 5,62 t/ha, which was for 0,12 and 0,16 t/ha more than the variant using the seeding machine ATD-6.35 without tillage and seeding machine SZ-3.6 on surface tillage. Analysis of winter wheat grain showed, that the protein and gluten contents in samples of variants 1 and 2, where the ATD-6.35 used were higher compared to variant 3, where the SZ-3.6 used and amounted respectively to 12,7-13,3 and 24,0$25,3 \%$.

At direct seeding observed the increasing the prime cost of 1 ton of grain, reducing the profitability and the energy efficiency ratio, as compared to the surface tillage and seeding with sowing machine ATD6.35, respectively, by $124 \mathrm{UAH}, 38,8 \%$ and 1,17, and at seeding with SZ-3,6 - for $164 \mathrm{UAH}, 53,5 \%$ and 1,18 .

Key words: winter wheat, soil tillage, seeding methods, crop yield, grain quality, economic and bioenergy efficiency.

Winter wheat along with high crop yield ability and grain quality, also characterized by increased resistance to stressful environmental conditions, makes it possible to significantly reduce the production costs of labor and resources at its growing and increase the sustainability of grain production. Growing highly welladapted varieties is one of the cheapest ways to meet the challenges of saving as well as provides an opportunity to increase crop yield and improve its quality with little additional cost. Important in such event is high environmental requirements to soil structure and to predeces- sors [1-3].

Winter wheat has high requirements to soil structure and to predecessor. Growing it according to biological requirements always increases productivity. When implementing scientifically based soil tillage made the rotation factor as element of biological agriculture. It stabilizes productivity level even without fertilization. Soil tillage and sowing systems of winter wheat have a positive effect on water and nutrient regimes of the soil, and in combination with fertilizers and other means of growing technology yields increased by $35-50 \%$ at stable indicators of soil

Інформація про авторів:

Gyrka Anatoliy Dmytrovych, Doctor of Agricultural Sciences, Professor, Head of the Laboratory of Agrobiological Resources of Spring Cereal and Pulse Crops, e-mail: adgyrka@gmail.com, https://orcid.org/0000-0002-2521-502X

Vinyukov Oleksandr Oleksandrovich, Ph. D. in Agricultural Sciences, Director, e-mail: alex.agronomist@gmail.com, https://orcid.org/0000-0002-2957-5487

Gyrka Tetiana Volodymyrivna, Candidate of Agricultural Sciences, Senior Researcher, Leading Researcher of the Laboratory of Plant Protection, e-mail: tvgyrka@gmail.com, https://orcid.org/0000-0002-5769-3384

Bokun Oleksandr Ivanovych, Candidate of Agricultural Sciences, Head of the Laboratory of Economic Analysis, Testing and Implementation of Scientific Developments, e-mail: alexbokun79@gmail.com, https://orcid.org/0000-0001-6559-6819

Kulyk Alla Oleksiivna, Chief Specialist of the Laboratory of Economics, e-mail: alla_kulik@ukr.net, https://orcid.org/0000-0002-8366-2397 
fertility. In the current socio-economic farming conditions, aggravated by climate change, the development and implementation a varietal agro-technology of most adapted grain crops in specific soil and climatic conditions and the development of resource-saving technology elements based on the fullest possible use of plants biological potential has a practical interest and is an actual problem for modern plant growing [4-7].

Material and methods. Production testing the feasibility of using soil tillage and sowing systems of winter wheat were carried out in SE EF "Dnipro" IGC NAAS in Soloniansky district, Dnipropetrovs'k region (field № 7, division № 2) during 2008-2010 in crop rotation link: pea - winter wheat - sunflower.

In field experiment were studied the effectiveness of these technological schemes of winter wheat growing variety Kuial'nyk: 1 - notillage, seeding with seeding machine ATD-6.35; 2 - surface tillage, seeding with seeding machine ATD-6.35; 3 - surface tillage, seeding with SZ-3.6. In variant 1 after harvesting predecessor and regrowth of weeds (on August) used a herbicide mixture (vulkan - 4 l/ha + esteron 1 1/ha). Technology of surface tillage (var. 2 and 3) included soil disking with BDT-7 at a depth of $8-10 \mathrm{~cm}$, subsurface loosening with combined aggregate KR-4,5 at a depth of $10-12 \mathrm{~cm}$, pre-sowing cultivation with KPS-4 at a depth of 6-8 cm. Other agro-technical elements - were generally accepted for Steppe zone [8, 9].

Seeding rate of winter wheat was 5 million pcs. of germinated seeds/ha. Sowing time - October, 1. At the end of tillering phase of plants in spring the sowings were locally dressed by ammonium nitrate $\left(\mathrm{N}_{30}\right)$.

Results and discussion. Weather conditions during 2008-2009 were favorable for winter wheat growing. Abundant rains in the second half of September have created good prerequisites for obtaining even sprouts and plant establishment.

At the time of sowing winter wheat (01.10), the productive moisture reserves in the top soil $(0-10 \mathrm{~cm})$ were sufficient for the emergence of seedlings. The average daily temperature of the first decade of October was $13,8{ }^{\circ} \mathrm{C}$, the second $11,0^{\circ} \mathrm{C}$ and the third $8,0^{\circ} \mathrm{C}$, that exceeded the average long-term data for this indi- cator by $3,0^{\circ} \mathrm{C}, 2,2^{\circ}$ and $2,2{ }^{\circ} \mathrm{C}$ respectively. This contributed to the early and even sprouts. In October and November observed elevated air temperature conditions.

Ceasing of autumn vegetation (CAV) of winter wheat was marked only on December, 8 . Wintering of crops was successful. Retrieval of spring vegetation (RSV) of winter wheat plants was marked on March, 30 in the period which was close to the long-time average annual date. Weather conditions of the winter period contributed to the good overwintering of wheat winter. The general physiological state of plants and shoots at the time of the restoration of spring vegetation was evaluated as good. This is confirmed by the results of the growth of winter plants in soil monoliths.

In general, the spring months were cool. Thus, April was dry, but due to rain fall in May, the winter wheat was well developed. In general, the development and spreading of diseases and pests in winter wheat crops was not rampancy, revealed differences in terms of their harmfulness for different tilling and sowing technologies were non-substantial and could not be considered as a determining factor in terms of the possible impact on the formation of winter wheat productivity.

The heading phase in all variants of the experiment was marked on June, 3 , and the complete grain ripeness was fixed on July, 7. The analysis of the structural productivity elements of winter wheat plants, which was determined by selecting the test shears in the pre-harvest period, showed that at direct seeding of winter wheat using the seeding machine ATD-6.35 contributed to an increase in the indicators of the density of productive stems for 7,4 and $20,9 \%$, a decrease in the grain weight out of 1 ear for $0,11-0,27 \mathrm{~g}$ and the weight of 1000 grains for 2,8-4,7 g compared with the use of surface tillage and seeding with seeding machine ATD6.35 and SZ-3.6. The highest grain yield of winter wheat was formed in the variant that mentioned a surface soil tillage andseeding with ATD-6.35 and was 5,62 t/ha, which was for 0,12 and $0,16 \mathrm{t} / \mathrm{ha}$ more than the variant using the seeding machine ATD-6.35 without tillage and seeding machine SZ-3.6 on surface tillage. The combination and correlation of these indicators and determines the level of the formed crop 
yield. Thus, the highest grain yield of winter wheat was formed in the variant that mentioned a surface soil tillage and seeding with ATD-6.35 and was 5,62 t/ha, which is 0,12 and $0,16 \mathrm{t} / \mathrm{ha}$ more than the variant using the seeding machine ATD-6.35 without tillage and seeding machine SZ-3.6 on surface tillage (Fig. 1).

Scientifically substantiated application of

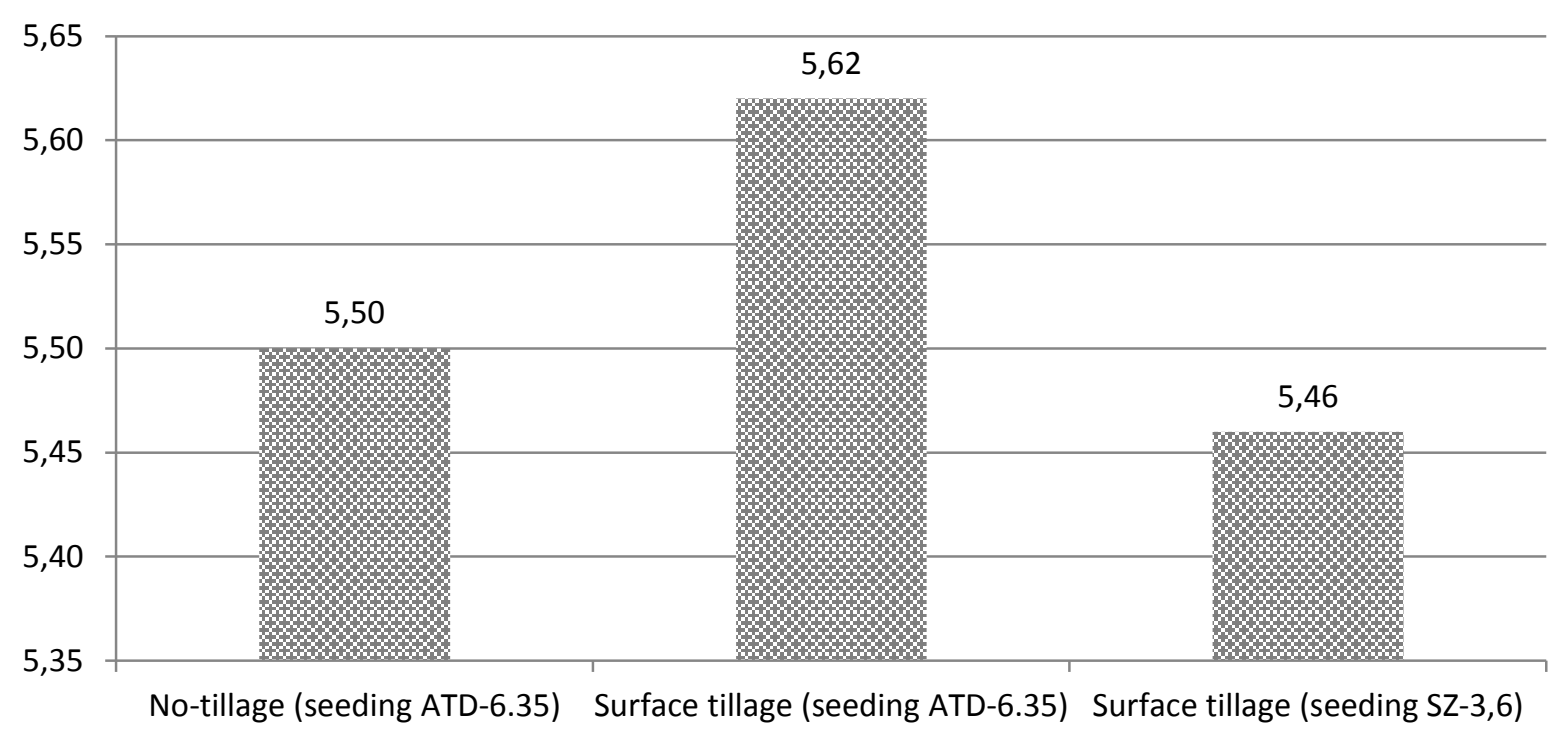

Fig. 1. Grain yield of winter wheat (t/ha), depending on the soil tillage and sowing systems.

growing technology based on no-tillage system and direct seeding with ATD-6.35 resulted in an increase in grain protein content up to $13,3 \%$ and gluten - to $25,3 \%$, which corresponds to the requirements of class 2 . As a result on the variant 1 (no-tillage and seeding with ATD-6.35, these indicators were at grain class 3 (respecttively 11,7 and $22,9 \%$ ). Improvement of the parameters of grain quality at direct seeding of winter wheat in 2009 is due to the formation of small grains in this variant. Thus, at the lower grain-unit mass, the proportion of proteins relative to carbohydrates (starch) is proportional grows. Thus, by the results of research was not installed the significant changes between the variants of experiment on the influence of tilling technologies on effective soil fertility and chemical composition of plants. Some trends that determined were of a general character.

Transferring the obtained indexes of yield structural elements of winter wheat into the program of mathematical processing we got a graphical model in which the corresponding parameters are displayed in each of the three lines variants of tilling and sowing methods, wherein: the thin continuous line shows the notillage, seeding with sowing machine ATD-6.35; heavy continuous line - surface tillage, seeding with sowing machine ATD-6.35 and hatched line- surface tillage, seeding with SZ-3,6. The value of each of 8 variables laid off by one of the radiuses in order to better compare cases with multi-dimensional view (Fig. 2).

Analysing the graphical model, it should be noted that at no-tillage and sowing with ATD-6.35 observed the highest manifestation of the 3 elements of the structure (amount of productive tillers per unit area, coefficient of productive tillering and the length of the head), and at the surface tillage and sowing with SZ-3,6 of 4 other (plant height, amount and weight of grains per head, 1000 grains weight). Only at the surface tilling and sowing method (with ATD 6.35), we noted the almost equal expression of the 5 structure elements, which, even at a significant reduction in plant height and reducing the number of grains per head, have provided formation the largest grain yield in experiment $5,62 \mathrm{t} / \mathrm{ha}$.

By the in-depth analysis of the economic efficiency of using the different methods of soil tillage and sowing systems shows that despite the fuel economy and the reduction of labor costs due to the direct sowing of winter wheat in unprocessed soil by the ATD-6.35 complex, in comparison with the generally accepted growing technology, a significant increases in production costs and total energy costs were noted. At the 


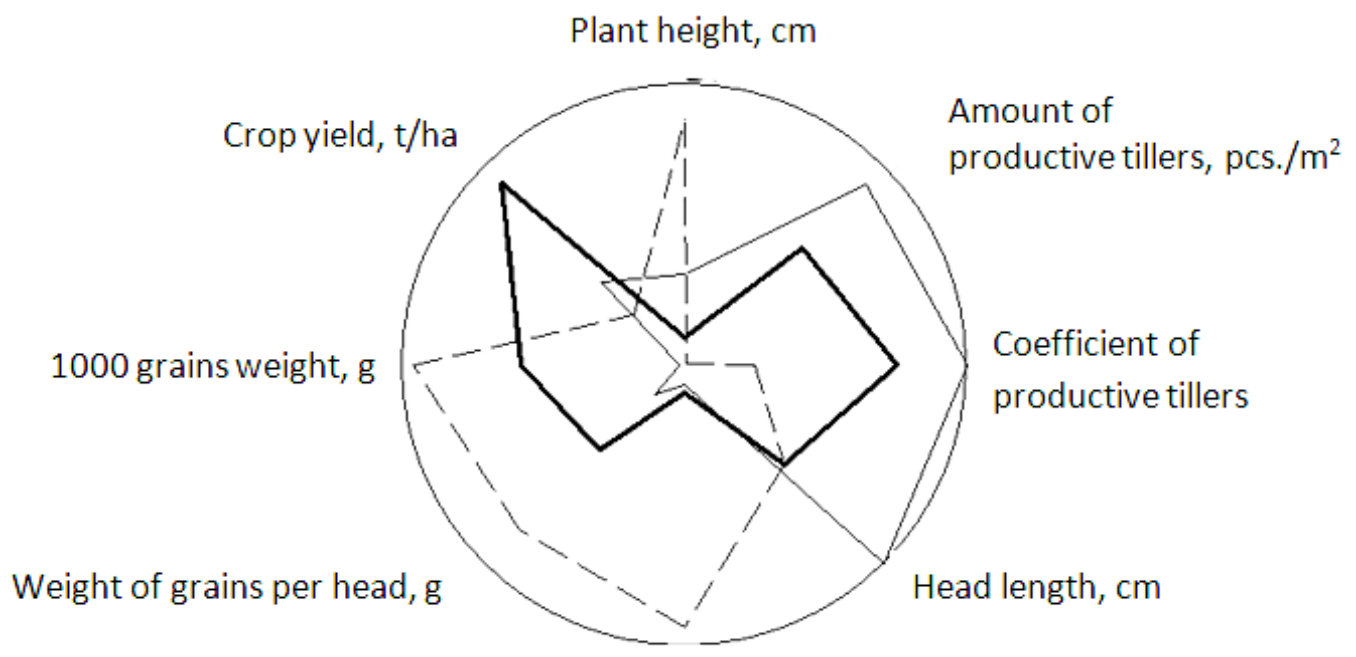

Amount of grains per head, pcs.

Fig. 2. Graphical display of structure elements and grain yield of winter wheat depending on the tilling and seeding systems.

same time, at no-tillage, the total production costs for the purchasing and application of herbicides and the using of energy-intensive (expensive in purchasing and servicing) of the complex of sowing machines that do not cover the expenses by the corresponding increasing in crop yield, which leads to a significant rising in products prices. Therefore, even in spite of sim- plification of the production cycle, at the direct seeding increases the prime cost of 1 ton of grain, reduces the profitability and the energy efficiency ratio, as compared to the surface tillage and seeding with sowing machine ATD-6.35, respectively, by $124 \mathrm{UAH}, 38,8 \%$ and 1,17 , and at seeding with SZ-3,6 - for $164 \mathrm{UAH}, 53,5 \%$ and 1,18 (Table).

\section{Economic and bioenergy efficiency of winter wheat growing after peas at different methods of soil tillage and sowing systems}

\begin{tabular}{|l|c|c|c|}
\hline \multirow{2}{*}{\multicolumn{1}{|c|}{ Indicators }} & \multicolumn{3}{|c|}{ Method of soil tillage and sowing systems } \\
\cline { 2 - 4 } & No-tillage, seeding & Surface tillage, seeding with \\
\cline { 3 - 4 } & with ATD-6.35 & ATD-6.35 & SZ-3.6 \\
\hline Crop yield, t/ha & 5,50 & 5,62 & 5,46 \\
\hline Production costs per 1 hectare, UAH & 6082 & 5518 & 5143 \\
\hline Prime cost of 1 ton of grain, UAH & 1106 & 982 & 942 \\
\hline Profitability, \% & 207,5 & 246,3 & 261,0 \\
\hline Costs of total energy per 1 hectare, MJ & 10948 & 9802 & 9521 \\
\hline Energy intensity 1 ton of grain, MJ & 1991 & 1744 & 1744 \\
\hline Energy efficiency ratio & 8,26 & 9,43 & 9,44 \\
\hline
\end{tabular}

Thus, direct seeding of winter wheat with sowing machine ATD-6.35 contributed to an increasing in the indicators of density of productive stems by 7,4 and $20,9 \%$, and decreasing in the weight of grain out of an ear by $0,11-0,27 \mathrm{~g}$, and the weight of 1000 grains - by $2,8-4,7 \mathrm{~g}$ in comparison with the use of surface tillage and seeding with sowing machines ATD-6.35 and SZ-3.6.

The highest crop yield of winter wheat grain was formed in the variant that provided a surface tillage and seeding with sowing machines ATD-6.35 and was 5,62 t/ha, which is 0,12 and $0,16 \mathrm{t} / \mathrm{ha}$ more than the variant using the sowing machine ATD-6.35 at no-tillage and SZ3.6 at surface tillage.

\section{Conclusions}

Thus, based on the results of researches on the efficiency of winter wheat growing systems, the following conclusions can be led. Applying 
the direct seeding of winter wheat using the seeding machine ATD-6.35 contributed to an increase in the indicators of the density of productive stems for 7,4 and $20,9 \%$, a decrease in the grain weight out of 1 ear for $0,11-0,27 \mathrm{~g}$ and the weight of 1000 grains for 2,8-4,7 g compared with the use of surface tillage and seeding with seeding machine ATD-6.35 and SZ-3.6.

The highest grain yield of winter wheat was formed in the variant that mentioned a surface soil tillage and seeding with ATD-6.35 and was 5,62 t/ha, which was for 0,12 and $0,16 \mathrm{t} / \mathrm{ha}$ more than the variant using the seeding machine ATD-6.35 without tillage and seeding machine

\section{Використана література}

1. Сайко В. Ф. Наукові основи землеробства в контексті змін клімату. Вісн. аграр. науки. 2008. № 11. C. 5-10.

2. Медведев В. В., Лактіонова Т. М., Донцова Л. В. Просторовий i часовий дефіцити зволоження сільськогосподарських культур на орних землях України. Вісн. аграр. науки. 2011. № 3. C. 9-13.

3. Гирка А. Д. Формування врожайності та якості зерна озимої пшениці залежно від підживлення i засобів захисту в умовах північного Степу України: дис. ... канд. с.- г. наук: спец. 06.01.09 / А. Д. Гирка. Дніпропетровськ, 2007. 177 с.

4. Гирка А. Д. Агробіологічні основи формування продуктивності озимих та ярих зернових культур у Північному Степу України: дис. ... доктора с.-г. наук: 06.01.09 / Гирка Анатолій Дмитрович. Дніпропетровськ. 2015. 353 с.

5. Кириленко В. В., Костромітін В. М., Корчинський А. А. Формування сортової структури зернових колосових культур за агроекологічним принципом. Вісн. аграр. науки. 2002. № 4. С. 26-28.

6. Лихочвор В. В. Біологічне рослинництво. Львів: НВФ Українські технології, 2004. 312 с.

7. Gyrka A. D., Bokun O. I., Viniukov O. O., Ischenko V. A., Gyrka T. V. Features of realization the productivity potential of winter and spring wheat varieties in Northern Steppe of Ukraine. Бюлетень Інституту сільського господарства степової зони НААН Украӥни. 2016. № 11. С. 49-53.

8. Доспехов Б. А. Методика полевого опыта (с основами статистической обработки результатов исследований). 5-е изд., доп. и перераб. Москва: Агропромиздат, $1985.352 \mathrm{c}$.

9. Методические рекомендации по проведению полевых опытов с зерновыми, зернобобовыми и кормовыми культурами; под ред. В. С. Цыкова и Г. Р. Пикуша. Днепропетровск, 1983. 46 с.

\section{References}

1. Sayko, V. F. (2008). Scientific fundamentals of agriculture in the context of climate change. Visnyk ah-
SZ-3.6 on surface tillage. Analysis of winter wheat grain in the phase of full ripeness showed, that the protein and gluten contents in samples of variants 1 and 2, where the ATD-6.35 used was higher compared to variant 3 and amounted respectively to $12,7-13,3$ and $24,0-25,3 \%$.

At the direct seeding increases the prime cost of 1 ton of grain, reduces the profitability and the energy efficiency ratio, as compared to the surface tillage and seeding with sowing machine ATD-6.35, respectively, by $124 \mathrm{UAH}$, $38,8 \%$ and 1,17 , and at seeding with SZ-3,6 for $164 \mathrm{UAH}, 53,5 \%$ and 1,18 .

rarnoyi nauky [Bulletin of Agrarian Science], 11, 510. [in Ukrainian]

2. Medvedev, V. V., Laktionova, T. M., Dontsova, L. V. (2011). Spatial and temporal deficiencies of humidification of crops in arable lands of Ukraine. Visnyk ahrarnoyi nauky [Bulletin of Agrarian Science], 3, 913. [in Ukrainian].

3. Gyrka, A. D. (2007). Formuvannya vrozhaynosti ta yakosti zerna ozymoyi pshenytsi zalezhno vid pidzhyvlennya i zasobiv zakhystu $v$ umovakh pivnichnoho Stepu Ukrayiny [Winter wheat grain yield and quality formation depending on fertilizing and means of protection in the Northern Steppe zone of Ukraine]. Dnipropetrovsk: N. p. 177. [in Ukrainian]

4. Gyrka, A. D. (2015). Ahrobiolohichni osnovy formuvannya produktyvnosti ozymykh ta yarykh zernovykh kultur u Pivnichnomu Stepu Ukrayiny [Agrobiological bases of formation the productivity of winter and spring cereals in the northern Steppe of Ukraine]. Dnipropetrovsk: N. p. 353. [in Ukrainian].

5. Kyrylenko, V. V., Kostromitin, V. M., Korchinsky, A. A. (2002). Formation of the varietal structure of grain cereal crops by agroecological principle. Visnyk ahrarnoyi nauky [Bulletin of Agrarian Science], 4, 26-28. [in Ukrainian].

6. Lykhochvor, V. V. (2004). Biolohichne roslynnytstvo. [Biological plant growing]. Lviv: NVF Ukrayinski tekhnolohiyi. [in Ukrainian]

7. Gyrka, A. D., Bokun, O. I., Viniukov, O. O., Ischenko, V. A., Gyrka, T. V. (2016). Features of realization the productivity potential of winter and spring wheat varieties in Northern Steppe of Ukraine. Byuleten Instytutu silskogo gospodarstva stepovoyi zony NAAN Ukrayiny [Bulletin of the Institute of Agriculture of the steppe zone of NAAS of Ukraine], 11, 49-53.

8. Dospekhov, B. A. (1985). Metodika polevogo opyta s osnovami statisticheskoy obrabotki rezul'tatov issledovaniy [Methodology of field experience with the basics of statistical processing of research results] $\left(5^{\text {th }}\right.$ ed. rev.). Moscow: Ahropromizdat. [in Russian]

9. Metodicheskiye rekomendatsii po provedeniyu polevykh opytov s zernovymi, zernobobovymi i kormovymi kul'turami. [Methodical recommendations for carrying out field experiments with grain, leguminous and 
УДК 633.11«324»:631.51/.53.04

Гирька А. Д., Винюков А. А., Гирька Т. В., Бокун А. И., Кулик А. А. Эффективность выращцвания пшеницы озимой в зависимости от системы обработки почвы и посева. Зерновые культуры. 2019. T. 3. № 1. С. 61-67.

Государственное учреждение Институт зерновых культур НААН, ул. Владимира Вернадского, 14, 2. Днепр, 49027, Украина

Представлены результаты опыта по производственной проверке и внедрению систем обработки почвы и посева пшеницы озимой. Освещена экономическая и биоэнергетическая эффективность выращиввани озими под влиянием исследуемых факторов.

На основании экспериментальных исследований установлено, что прямой посев пшениць озимой сеялкой АТД-6.35 обусловливал увеличение плотности продуктивного стеблестоя на 7,4 и 20,9 \% и уменьшение массы зерна с колоса на 0,11-0,27 2, а массы 1000 зерен на 2,8-4,7 г по сравнению с мелкой обработкой почвы и посевом сеялками АТД-6.35 и С3-3,6.

Самую высокую урожайность пшеница озимая сформировала в варианте с мелкой обработкой почвы и посевом сеялкой АТД-6.35 - 5,62 m/2а, что на 0,12 и 0,16 m/2а превынает варианты с использованием сеялки АТД-6.35 по нулевой обработке почвы и сеялки С3-3,6 - по мелкой.

Анализ зерна пшеницы озимой в фазе полной спелости показал, что содержание белка и клейковины в образцах зерна из вариантов 1 и 2, где посев осуществлялся посевным комплексом АТД-6.35, было выме по сравнению с вариантом 3 - соответственно 12,7-13,3 и 24,0-25,3\%.

При прямом севе пшениць озимой возрастала себестоимость $1 \mathrm{~m}$ зерна, снижался уровень рентабельности и уменьшался коэффициент энергетической эффективности по сравнению с мелкой обработкой почвы и посевом АТД-6.35 соответственно на 124 грн., 38,8 \% и 1,17, а при посеве СЗ3,6 - на 164 грн., 53,5\% и 1,18.

Ключевые слова: пшеница озимая, обработка почвы, способ посева, урожайность, качество зерна, экономическая и биоэнергетическая эффективность.

УДК 633.11«324»:631.51/.53.04

Гирка А. Д., Винюков О. О., Гирка Т. В., Бокун О. І., Кулик А. О. Ефективність вирощування пшениці озимої залежно від системи обробітку трунту та сівби. Зернові культури. 2019. Т. 3. № 1. C. 61-67.

Державна установа Інститут зернових культур НААН, вул. Володимира Вернадського, 14, м. Дніпро, 49027, Україна

Висвітлено результати досліду з виробничої перевірки та впровадження систем обробітку трунту й сівби пшениці озимої. З'ясовано економічну й біоенергетичну ефективність виромування озимини під впливом досліджуваних факторів.

В результаті експериментальних досліджень встановлено, щзо пряма сівба пшениці озимої сівалкою АТД-6.35 зумовлювало збільшення шільності продуктивного стеблостою на 7,4 i 20,9\% та зменшення маси зерна з колосу на 0,11-0,27 2, а маси 1000 зерен на 2,8-4,7 г порівняно з мілким обробітком трунту і сівбою сівалками АТД-6.35 і С3-3,6.

Найбільша врожайність зерна пшениці озимої була у варіанті з мілким обробітком трунту $i$ сівбою сівалкою АТД-6.35 - 5,62 m/2а, щзо на 0,12 ma 0,16 m/2а перевищувало показники варіантів з використанням сівалки АТД-6.35 по нульовому обробітку і сівалки С3-3,6 - по мілкому.

Аналіз зерна пшениці озимої в фазі повної стиглості показав, щзо вміст білка та клейковини в зразках зерна з варіантів 1 i 2, де сіяли посівним комплексом АТД-6.35, був вищим порівняно з варіантом 3 і становив відповідно 12,7-13,3 і 24,0-25,3\%.

За прямої сівби пшенищі озимої підвищувалась собівартість 1 m зерна, знижувалась рентабельність і зменшувався коефічієнт енергетичної ефективності порівняно з мілким обробітком трунту і сівбою АТД-6.35 відповідно на 124 грн, 38,8\% та 1,17, а за сівби С3-3,6 - на 164 грн, 53,5 \% ma 1,18 .

Ключові слова: пшениия озима, обробіток трунту, спосіб сівби, урожайність, якість зерна, економічна та біоенергетична ефективність. 